\title{
KONTRIBUSI RESILIENSI MATEMATIS TERHADAP KEMAMPUAN AKADEMIK MaHaSisWA PADA MATa KUliah STATISTIKa MATEMATIKA
}

\section{Contribution of MATHEMATiCAl RESilience to STUDENT'S ACADEMic ABility in MATHEMATiCAl Statistics CourSE}

\author{
Luvy Sylviana Zanthy \\ Prodi Pendidikan Matematika, IKIP Siliwangi \\ Jln. Terusan Jendral Sudirman, Cimahi, Jawa Barat, Indonesia \\ Lszanthy@gmail.com
}

\begin{abstract}
Abstrak
Penelitian ini bertujuan untuk mengetahui hubungan antara resiliensi matematis dengan kemampuan akademik mahasiswa pada mata kuliah Statistika Matematika. Penelitian ini didasari oleh capaian akademik pada mata kuliah Statistika Matematika yang tergolong rendah. Mahasiswa merasa kesulitan dan mudah menyerah dalam menyelesaikan soal. Metode yang digunakan dalam penelitian ini adalah adalah metode survey dengan teknik korelasi. Populasi dalam penelitian ini adalah seluruh mahasiswa program studi pendidikan matematika IKIP Siliwangi, sampel penelitian diambil dengan teknik purposive sampling sebanyak 30 orang mahasiswa yang mengambil mata kuliah Statistika Matematika. Instrumen dalam penelitian ini berupa soal tes uraian kemampuan akademik dan soal non tes berupa skala resiliensi matematis. Hasil penelitian menunjukkan bahwa terdapat hubungan yang positif antara resiliensi matematis dengan kemampuan akademik mahasiswa, dengan kontribusi resiliensi matematis sebesar 48,5 \% terhadap kemampuan akademik mahasiswa.

Kata Kunci: Resiliensi matematis, kemampuan akademik, statistika matematika.
\end{abstract}

\begin{abstract}
The aims of this study was to determined the relationship between mathematical resilience with academic ability of students' in Mathematics Statistics. This research is based on low academic achievement of students in Mathematics Statistics course. Students find difficulty and easily give up in solving the problem. The method used in this research is survey method with correlation technique. Population in this research is all student in study program of mathematics in IKIP Siliwangi, research sample is taken by purposive sampling technique as many as 30 students who take on Mathematics Statistics course. The Instruments in this study are test description of academic ability questions and non test questions in the form of mathematical resilience scale. The results showed that there was a positive correlation between mathematical resilience and student's academic ability, with mathematical resilience contribution of $48,5 \%$ to student's academic ability.

Keyword: Mathematical resilience, academic ability, mathematical statistics.
\end{abstract}




\section{Pendahuluan}

Statistika Matematika adalah salah satu mata kuliah yang harus diampu mahasiswa Pendidikan Matematika di IKIP Siliwangi. Sebagian besar mahasiswa masih menganggap bahwa mata kuliah ini termasuk materi yang sulit dipahami. Mahasiswa masih banyak kesulitan menyelesaikan soal yang dosen berikan, ini dibuktikan dengan capaian akademik mahasiswa pada mata kuliah Statistika Matematika pada Tahun Ajaran 2015/2016 yang masih tergolong rendah.

Situasi di atas seharusnya tidak perlu terjadi, karena materi di dalam mata kuliah statistika matematika bukan materi yang baru bagi mahasiswa. Sebelumnya, mahasiswa sudah mempelajari statisika dasar dan statistika penelitian. Tanggung jawab yang sangat besar tentunya dipikul oleh dosen yang mengampu mata kuliah tersebut dan diperlukan kajian secara cermat serta mendalam untuk mengatasi permasalahan tersebut.

Berdasarkan wawancara dengan beberapa mahasiswa, sebab di atas dikarenakan faktor internal dan eksternal mahasiswa tersebut. Menurut (Syah, M., 2000), Faktor yang mempengaruhi menurunnya prestasi akademik adalah:

(1) Faktor internal, yaitu faktor yang berasal dari dalam mahasiswa itu sendiri, yaitu faktor fisiologis yang bersifat bawaan atau yang bukan bawaan/yang diperoleh dan faktor psikologis yang bersifat intelektual dan non intelektual.
(2) Faktor eksternal yaitu faktor yang berasal dari luar diri mahasiswa, contohnya: kurikulum, guru, metode, faktor sosial, faktor budaya, dan faktor lingkungan.

Pembelajaran yang inovatif merupakan salah satu solusi untuk mengatasi kesulitan mahasiswa tersebut, seorang dosen biasanya memilih dan melaksanakan pendekatan pembelajaran tertentu dan berusaha menumbuhkan sikap positif terhadap matematika dan belajar matematika. Salah satu sikap positif yang merupakan bahan kajian dari penelitian ini adalah resiliensi matematis. Mahasiswa yang memiliki resiliensi yang kuat mereka akan mengatasi hambatan dalam belajar matematika dan mampu menyelesaikan soal-soal matematika yang sulit.

Resiliensi adalah kemampuan seseorang untuk menilai, mengatasi, dan meningkatkan diri ataupun mengubah dirinya dari keterpurukan atau kesengsaraan dalam hidup, karena setiap orang itu pasti mengalami kesulitan ataupun sebuah masalah dan tidak ada seseorang yang hidup di dunia tanpa suatu masalah ataupun kesulitan (Grotberg, E., 1995).

Johnston-Wilder, S. \& Lee, C. (2008, $2010^{a}$ ) berpendapat bahwa resiliensi matematis adalah sebuah konsep penting dalam pendidikan, karena masih banyak siswa mengalami kesulitan dan kegagalan dalam mempelajari matematika. Siswa yang memiliki resiliensi matematis mempunyai kemampuan untuk 
menumbuhkan kepercayaan dirinya. Mereka menganggap bahwa matematika itu bukan merupakan hambatan, bahkan ketika siswa itu sendiri mengalami kesulitan, dia akan mempertahankan kepercayaan dirinya sampai berakhir sukses. Dia tidak akan segan membantu teman/kelompoknya berdasarkan pengetahuan yang dimilikinya dan dapat memanfaatkan bantuan dan dukungan temannya apabila diperlukan.

Pakar lainnya, Yeager \& Dweck (2012) mendefinisikan resiliensi sebagai "perilaku, atribusi (suatu unsur dari proses persepsi yang bisa sangat mempengaruhi sikap/tingkah laku seseorang), atau respons emosional terhadap tantangan akademis atau sosial yang positif atau bermanfaat untuk pembangunan. Adanya resiliensi disebabkan karena adanya beberapa hambatan yang dihadapi yang diikuti dengan hasil yang positif. Dalam konteks matematika, hambatan tersebut dapat berupa kelas yang gagal, berjuang melampaui toleransi, kebosanan, rasa malu karena kinerja buruk, kurikulum atau instruksi berkualitas rendah, dan tidak adanya interaksi guru-siswa atau antara siswa dengan siswa.

Kooken, J. Welsh, M.E., Mccoach, D.B., Johnson-Wilder, S and Lee (Sumarmo, 2015) mengkonsepkan resiliensi matematik sebagai sikap positif terhadap matematika yang memberi kesempatan siswa tetap melanjutkan belajar matematika meski menghadapi kesulitan.

Menurut (Johnston-Wilder, S., 2013), berdasarkan teori yang dikemukakan oleh
Johnston-Wilder, S. \& Lee, C. $\left(2010^{\mathrm{b}}\right)$ terdapat empat faktor yang berkorelasi dengan resiliensi, yaitu:

(1) Value: Keyakinan bahwa matematika adalah subjek yang berharga dan patut dipelajari;

(2) Struggle: Pengakuan bahwa perjuangan dengan matematika bersifat universal bahkan dengan orang-orang yang memiliki kemampuan matematika tingkat tinggi;

(3) Growth: Keyakinan bahwa semua orang dapat mengembangkan keterampilan matematika dan ketidakpercayaannya bahwa beberapa orang dilahirkan dengan atau tanpa kemampuan untuk belajar, dan

(4) Resillience: Orientasi terhadap situasi atau kesulitan negatif dalam pembelajaran matematika yang menghasilkan respons positif.

Faktor pertama, value, Chouinard, R. \& Roy, N. (2007) berpendapat dalam konteks prestasi akademik, teori ini mengemukakan bahwa siswa akan lebih tertarik dan lebih termotivasi untuk belajar matematika jika mereka percaya itu berharga. Dalam konteks ini, nilai ditentukan oleh persepsi siswa tentang pentingnya matematika bagi kehidupan dan dunia mereka. Semakin berharga siswa memahami matematika, semakin besar motivasi untuk mempelajarinya, dan semakin besar kemungkinan mereka bertahan dalam menghadapi kesulitan. 
Faktor kedua, struggle, didasarkan pada teori dari Bandura, A. (1989) yaitu kemampuan untuk mengendalikan proses pemikiran, motivasi, dan tindakan seseorang. Masih menurut (Bandura, A., 2000) bahwa semakin tinggi tingkat keberhasilan sekelompok orang, semakin tinggi motivasi kelompok dalam usaha mereka, semakin kuat daya tahan mereka dalam menghadapi hambatan dan kemunduran, dan semakin besar pencapaian hasil kinerja mereka.

Faktor ketiga, Growth, mengacu pada keyakinan bahwa pengetahuan matematika tidak tetap dan pertumbuhan itu mungkin terjadi. Menurut teori pertumbuhan Dweck tentang pembelajaran (Dweck, C., 2000), siswa yang menghubungkan kesuksesan mereka dengan faktor internal memiliki orientasi tujuan, mereka mencari tantangan dan mengembangkan strategi untuk menghadapi kesulitan, begitupun sebaliknya.

Faktor keempat, Resillience, mengacu pada pada literatur resiliensi psikologis yang mencakup pemaparan terhadap ancaman yang diikuti oleh respon positif terhadap pembelajaran matematika. Menurut (Bandura, A., 1989), Pada kenyataannya, untuk menghadapi kesulitan harus mempunyai pengetahuan dan kompetensi serta upaya yang berkelanjutan dalam mengahadapi kesulitan tersebut. Oleh karena itu faktor ini menggabungkan dua buah komponen, yaitu pengalaman seseorang dalam mengahadapi kesulitan serta respon positif seseorang untuk menghadapi kesulitan tersebut.

Sedangkan menurut (Richardson dalam Henderson, N. \& Milstein, M.M., 2003), terdapat dua faktor yang membentuk resiliensi, yaitu faktor Protektif Internal dan faktor protektif eksternal.

Faktor protektif internal yaitu karakteristik individu yang membentuk resiliensi: bersedia melayani orang lain, menggunakan life skills, termasuk pengambilan keputusan yang baik, assertivitas, impulse control dan pemecahan masalah, Sosialibilitas (kemampuan untuk menjadi teman, kemampuan untuk membetuk hubungan yang positif), memiliki selera humor, Internal locus of control, Otonomi (kemandirian), memiliki sudut pandang positif tentang masa depan, fleksibilitas, memiliki kapasitas untuk belajar, motivasi diri, memiliki keahlian (kompetensi personal), memiliki perasaan self-worth dan kepercayaan diri.

Faktor Protektif Eksternal adalah karakteristik keluarga, sekolah, komunitas dan kelompok teman sebaya yang mengembangkan resiliensi: memiliki ikatan yang kuat, menjunjung tinggi pendidikan, menggunakan gaya interaksi yang penuh kehangatan dan tidak menghakimi, membuat batasan-batasan yang jelas (peraturan, norma dan hukum), mendorong hubungan yang supportif dengan orang lain, melestarikan tanggung jawab, saling melayani, "required helpfullness", menyediakan akses akan kebutuhan dasar rumah tangga, 
pekerjaan, kesehatan dan rekreasi, menunjukkan harapan kesuksesan yang tinggi dan realistis, mendorong pembuatan tujuan dan mastery, mendorong perkembangan prososial akan nilai-nilai (misalnya altruisme) dan life skills (misalnya kerja sama), menyediakan kepemimpinan, pengambilan keputusan, dan kesempatan-kesempatan lain untuk partisipasi yang berarti dan menghargai talenta unik dari masing-masing individu.

Reivich, A. \& Shatte, A. (2002) berpendapat, ada tujuh kemampuan yang membentuk resiliensi, yaitu :

(1) Pengendalian emosi

(2) Kemampuan untuk mengontrol impuls.

(3) Optimis

(4) Kemampuan untuk menganalisis penyebab dari masalah

(5) Kemampuan untuk berempati

(6) Self-efficacy

(7) Kemampuan untuk meraih apa yang diinginkan.

Berdasarkan latar belakang yang telah diuraikan di atas, maka rumusan masalah dalam penelitian ini adalah:

(1) Bagaimanakah gambaran secara umum resiliensi matematis mahasiswa?

(2) Bagaimanakah gambaran secara umum kemampuan akademik mahasiswa?

(3) Apakah terdapat hubungan antara resiliensi matematis dengan kemampuan akademik mahasiswa?
(4) Berapa besar kontribusi resiliensi matematis terhadap kemampuan akademik mahasiswa?

Tujuan dari penelitian ini adalah untuk mengetahui:

(1) Gambaran secara umum resiliensi matematis mahasiswa.

(2) Gambaran secara umum kemampuan akademik mahasiswa.

(3) Hubungan antara resiliensi matematis dan kemampuan akademik mahasiswa. Kontribusi resiliensi matematis terhadap kemampuan akademik mahasiswa.

\section{Metode}

Metode dalam penelitian ini adalah metode survey dengan teknik korelasi yaitu mencari hubungan antara resiliensi matematis dan kemampuan akademik mahasiswa.

Populasi penelitian ini adalah seluruh mahasiswa Prodi Pendidikan Matematika di IKIP Siliwangi. Pengambilan sampel dilakukan dengan teknik purposive sampling, subjek sampelnya adalah 30 orang mahasiswa Prodi Pendidikan Matematika IKIP Siliwangi yang mengampu mata kuliah Statistika Matematika.

Instrumen dalam penelitian ini adalah instrumen tes dan non tes, Instrumen tes berupa 5 buah soal berbentuk uraian kemampuan akademik mahasiswa yang sebelumnya telah di uji cobakan untuk mengetahui validitas, reliabilitas, tingkat kesukaran dan daya pembeda dari setiap soal agar soal yang akan dipakai untuk penelitian tersebut valid dan reliabel. 
Instrumen non tes dalam penelitian ini berupa skala resiliensi matematis yang terdiri dari 30 pernyataan serta dilengkapi dengan 4 pilihan jawaban, yaitu Sering sekali (SS), Sering (S), Jarang (J) dan Jarang Sekali (JS). Jawaban responden di ukur dengan menggunakan skala Lykert yang bernilai 1 sampai 4 dari setiap soalnya. Uji kelayakan skala resiliensi dilakukan oleh 2 orang rekan sejawat dosen yang difokuskan pada validitas konstruk dan validitas isi. Semua perhitungan dalam penelitian ini berbantuan SPSS dan Microsoft Excel.

\section{Hasil dan Pembahasan}

\section{A. Hasil Penelitian}

Berikut disajikan hasil penelitian berupa gambaran secara umum resiliensi matematis dan kemampuan akademik mahasiswa, hasil uji korelasi untuk mengetahui seberapa kuat hubungan antara resiliensi matematis dengan kemampuan akademik mahasiswa, hasil uji signifikasi regresi untuk mengetahui besarnya pengaruh antara resiliensi matematis dengan kemampuan akademik mahasiswa dan hasil uji koefesien determinasi untuk mengetahui seberapa besar kontribusi resileinsi matematis terhadap kemampuan akademik mahasiswa yang mengampu mata kuliah statistika matematis.

Tabel 1.

Gambaran Umum Resiliensi Matematis (RM) dan Kemampuan Akademik Mahasiswa (KA)

\begin{tabular}{cccccc}
\hline Variabel & $\mathrm{N}$ & Max & Min & Mean & $\begin{array}{c}\text { Std } \\
\text { Dev }\end{array}$ \\
\hline RM & 30 & 77 & 35 & 43,78 & 9,671
\end{tabular}

\begin{tabular}{llllll|} 
KA & 30 & 63 & 31 & 57,45 & 8,336 \\
\hline
\end{tabular}

Berdasarkan hasil perhitungan pada tabel 1 , maka rata-rata reliensi matematis 43,78 dan standar deviasi 9,671 yang termasuk dalam kategori cukup. Sedangkan rata-rata kemampuan akademik mahasiswa 57,45 dan standar deviasi sebesar 8,336 yang termasuk dalam kategori rendah.

Tabel 2.

Hasil Uji Korelasi Resiliensi Matematis (RM) dan Kemampuan Akademik Mahasiswa (KA)

\begin{tabular}{lcl}
\hline Variabel & Korelasi & Keterangan \\
\hline $\mathrm{RM}><\mathrm{KA}$ & 0,705 & Positif, kuat
\end{tabular}

Berdasarkan tabel 2, dapat dilihat bahwa hubungan antara resiliensi matematis dengan kemampuan akademik mahasiswa sebesar 0,705, artinya tingkat hubungan kedua variabel kuat. Dengan demikian dapat diartikan bahwa terdapat hubungan yang signifikan dan positif antara resiliensi matematis dan kemampuan akademik mahasiswa.

Tabel 3.

\begin{tabular}{lllllll}
\multicolumn{7}{c}{ Hasil Uji Signifikansi Regresi } \\
\hline $\begin{array}{l}\text { M } \\
\text { od } \\
\text { el }\end{array}$ & $\begin{array}{l}\text { Sum of } \\
\text { Square }\end{array}$ & Df & $\begin{array}{c}\text { Mean } \\
\text { Square }\end{array}$ & F & Sig. & $\begin{array}{c}\text { M } \\
\text { od } \\
\text { el }\end{array}$ \\
\hline 1 & & & & & & \\
& Regres & 676, & 1 & 676, & 17, &, 00 \\
& sion & 856 & & 856 & 454 & $1^{\text {a }}$ \\
\cline { 2 - 7 } & Residu & 710, & 18 & 38,2 & & \\
& al & 523 & & 89 & & \\
\cline { 2 - 7 } & Total & 1387 & 18 & - & & \\
& &, 379 & & & &
\end{tabular}

Berdasarkan tabel 3. diperoleh nilai $F$ hitung sebesar 17,454 dan Sig. sebesar 0,001 . Dikarenakan nilai signifikansi $>0,05$, ini berarti resiliensi matematis 
berpengaruh signifikan terhadap kemampuan akademik mahasiswa.

Tabel 4.

Hasil Uji Koefesien Determinasi

\begin{tabular}{ccccc}
\hline Model & $\mathbf{R}$ & $\begin{array}{c}\mathrm{R} \\
\text { Square }\end{array}$ & $\begin{array}{c}\text { Adjusted } \\
\mathrm{R} \text { Square }\end{array}$ & $\begin{array}{c}\text { Std Error of } \\
\text { the } \\
\text { estimated }\end{array}$ \\
\hline 1 & $0,704^{\mathrm{a}}$ & 0,485 & 0,457 & 6,321
\end{tabular}

Berdasarkan hasil dari tabel 4. diperoleh bahwa nilai R Square sebesar 0,485 , sehingga nilai koefisien determinasinya adalah $=0,485 \times 100 \%$ $=48,5 \%$. Ini berarti bahwa kontribusi resiliensi matematis terhadap kemampuan akademik mahasiswa sebesar 48,5\% dan 51,5\% dipengaruhi oleh variabel lainnya.

\section{B. Pembahasan}

Berdasarkan hasil penelitian terhadap mahasiswa Program Studi Pendidikan Matematika IKIP Siliwangi diperoleh hubungan yang positif dan signifikan antara resiliensi matematis dengan kemampuan akademik mahasiswa pada mata kuliah Statistika Matematis.

Tidak begitu besarnya kontribusi resiliensi terhadap kemampuan akademik mahasiswa kemungkinan disebabkan beberapa faktor, diantaranya: Usia mahasiswa yang relatif masih muda (antara 18 sampai 20 tahun) sehingga masih sulit mengendalikan emosi, memusatkan perhatian dan perilaku. Seseorang yang memiliki resiliensi yang rendah cenderung lebih mengalami kecemasan, kesedihan, dan kemarahan dibandingkan dengan individu yang lain. Apabila mereka mengalami kekecewaan dan kesulitan pada saat menghadapi soal statistika matematika, mereka akan terjebak dalam kekecewaan dan kecemasan sehingga tidak dapat menyelesaikan masalah yang diberikan.

Faktor lainnya adalah kurangnya dukungan sosial dari keluarga dan lingkungan. Dukungan sosial ini berupa perasaan nyaman, perhatian atau penghargaan dari keluarga atau lingkungan. Dukungan sosial yang baik dapat menyebabkan sikap optimis dalam diri mahasiswa. Sikap optimis ini membuat fisik lebih sehat untuk belajar matematika dan tidak mudah mengalami depresi apabila menemukan soal yang sulit. Sikap optimis dapat membuat mahasiswa yakin akan kemampuannya dan dapat memecahkan masalah yang dihadapi., mencari solusi dan mampu memperbaiki situasi sesulit apapun.

Siswa yang mempunyai resiliensi tinggi, apabila mengalami kondisi sulit, dia mempunyai motivasi yang tinggi untuk mencapai prestasi akademiknya, sedangkan siswa yang mempunyai resiliensi yang rendah menganggap bahwa kesulitan yang dihadapi merupakan beban hidupnya, sehingga beban tersebut dianggap sebagai suatu ancaman dan cepat mengalami frustasi.

Menurut (Newman, 2004), agar seseorang mempunyai resiliensi yang tinggi, maka strategi yang harus dilakukan pada seseorang yang berusia 13 sampai 19 tahun adalah: Jaringan dukungan sosial yang kuat, berupa: 
(1) Kehadiran orang tua atau orang tua yang tanpa syarat selalu mendukung terhadap apa yang dilakukan anak.

(2) Adanya mentor yang berkomitmen atau orang lain dari luar keluarga.

(3) Pengalaman positif di sekolah sebelumnya.

(4) Mempunyai rasa percaya diri dan berusaha membuat perubahan

(5) Partisipasi dalam berbagai kegiatan ekstra kurikuler.

(6) Kemampuan untuk membingkai kembali kesulitan sehingga bermanfaat dan mengakui manfaat dari kesulitan tersebut.

(7) Kemampuan untuk 'membuat perbedaan' dengan membantu orang lain atau melalui kerja paruh waktu.

(8) Jangan berlindung dari situasi yang sulit, tetapi mengembangkan keterampilan untuk mengatasi kesulitan tersebut.

\section{Penutup}

Kesimpulan dari temuan yang diperoleh dalam penelitian ini adalah terdapat hubungan yang positif dan signifikan antara resiliensi matematis dengan kemampuan akademik mahasiswa. Artinya, resiliensi matematis dapat digunakan untuk memprediksikan tingkat kemampuan akademik mahasiswa.

Resiliensi matematis memiliki kontribusi sebesar 48,5\% terhadap kemampuan akademik mahasiswa dan 51,5\% dipengaruhi oleh variabel lainnya.
Resiliensi matematis yang ditelaah pada penelitian ini merupakan Resiliensi matematis yang terkait dengan kemampuan akademik mahasiswa pada mata kuliah Statistika Matematika. Peneliti selanjutnya diharapkan dapat meneliti Resiliensi matematis yang terkait dengan kemampuan matematis lainnya.

\section{Daftar PUstaka}

Bandura, A. (1989). Human agency in social cognitive theory. American Psychologist, 44(9), 1175-1184.

Bandura, A. (2000). Exercise of human agency through collective efficacy. Current Directions in Psychological Science, 9 (3), 75-78.

Chouinard, R. \& Roy, N. (2007). Relations among competence beliefs, utility value, achievement goals, and effort in mathematics. British Journal of Educational Psychology, 77, 501-517. Dweck, C. (2000). Self-theories: Their role in motivation, personality and development. Lillington NC: Psychology Press, Taylor \& Francis.

Grotberg, E. (1995). A Guide to Promoting Resilience in Children: Strengthening The Human Spirit. Benard Van Leer Fondation.

Henderson, N. dan Milstein, M.M. 2003. Resiliency in Schools. Making it Happen for Students and Educators. California, USA : Corwin Press, Inc. Johnston-Wilder, S., \& Lee, C. (2008). Does Articulation Matter When Learning Mathematics? Proceedings of the 
British Society for Research into Learning Mathematics, 28, 54-59.

Johnston-Wilder, S., \& Lee, C. (2010ª).

Developing Mathematical Resilience.

BERA Annual Conference 2010,

University of Warwick, 1-4 September 2010.

Johnston-Wilder, S. \& Lee, C. $\left(2010^{\mathrm{b}}\right)$. Mathematical resilience. Mathematics Teaching, 218, 38-41.

Johnston-Wilder, S. (2013) Measuring mathematical resilience : an application of the construct of resilience to the study of mathematics. In: AERA 2013, San Francisco, California, 27 Apr-1 May 2013 (Submitted).

Newman, T. (2004). What Works in Building Resilience? London, Barnardo's.

Reivich, K. \& Shatte, A. (2002). The Resilience Factor. New York: Random House, Inc.

Sumarmo, U. (2015). Resiliensi Matematik.

[Online]. Tersedia: http://utarisumarmo.dosen.stkipsiliwangi.ac.id/m ateri/resiliansi-matematik-

mathematical-resilience/. Diakses 10 Desember 2017.

Syah, M. (2000). Psikologi Pendidikan dengan Pendekatan Baru. Bandung: Rosdakoemar.

Yeager, D. \& Dweck, C. (2012). Mindsets

That Promote Resilience: When Students Believe That Personal Characteristics Can Be Developed. Educational Psychologist, 47, 302-314.

\section{Riwayat Hidup PENULIS} Luvy Sylviana Zanthy, S.P., M.Pd.

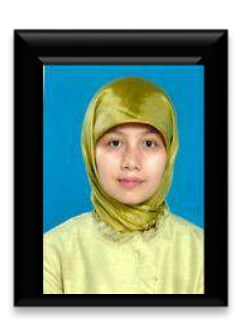

Lahir di Jakarta, 23 November 1977. Staf pengajar di IKIP Siliwangi. Studi S1 Ilmu Tanah di Universitas Padjadjaran, Bandung, lulus tahun 1999; S2 Pendidikan Matematika di Universitas Pendidikan tahun 2011.
Indonesia, Bandung, lulus 
This page is intentionally left blank 